\title{
Desafio da inovação
}

\section{Sebastião Carlos de Morais Squirra*}

CRUZ, Renato. Inovação. A revolução do conhecimento nas empresas brasileiras. São Paulo: Editora Senac, 2011. 237 p.

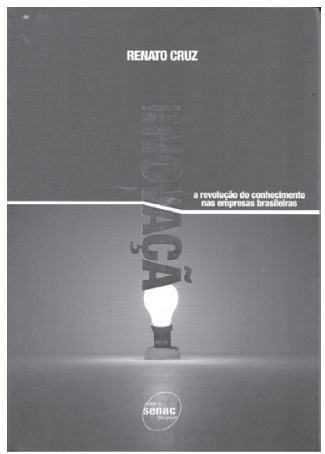

S incrônicas com os modelos internacionais de desenvolvimento, as diferentes instâncias científicas brasileiras proclamam que é fundamental investir em inovação, se a nação pleiteia evolução nos seus padrões de inserção no mundo globalizado. Este é o princípio que integra as atuais políticas de CT\&I (Ciência, Tecnologia e Inovação) do governo federal. É certo que para tanto, são necessários estágios intermediários de melhoria do ensino em todos seus níveis e de robustecimento dos padrões de ação governamental e de financiamento das pesquisas. Tudo isto, fortalecendo a união dos cientistas brasileiros com os diferentes setores produtivos locais.

Todavia, e como acontece com os demais países em evolução, o Brasil ainda se inicia nos processos que estimulem a criação científica de peso, obliterado pelas políticas tímidas do passado, mas também pelas inúmeras amarras do sistema capitalista mundialmente estruturado. Dessa forma, não restou outra saída que a de, na avassaladora parte de sua história, copiar e implantar no país modelos produtivos advindos do exterior. E acomodar a implantação das inovações obtidas alhures, com contribuição nula do país. Sabe-se que tal processo desestimula a inovação local e atrela a economia ao pagamento de direitos aos detentores estrangeiros, desestimulando o desenvolvimento regionalmente originado.

* Professor do Programa de Pós-Graduação em Comunicação da Universidade Metodista de São Paulo. Email: sebastiao.squirra@metodista.br 
Como se experimenta diariamente, nos tempos atuais um verdadeiro turbilhão tecnológico mistura amplos segmentos sociais num, até então, desconhecido caldeirão midiático, disponibilizando miríade de amigáveis e convergentes aparelhos, conectados em rede, com recursos até então inimagináveis. Mesmo que isto venha acontecendo já há algum tempo, no segmento da comunicação não é freqüente que autores escrevam sobre inovação, apesar do esforço que o país faz na direção deste importante princípio de evolução e crescimento. Logo nas primeiras páginas, Renato Cruz lembra Kevin Kelly que diz "inovar é mais do que somente ter uma ideia; também é preciso trazer todas as outras pessoas até onde a sua ideia está”, o que ressalta a importância da comunicação no processo de difusão do conhecimento. De fato, para os comunicadores, o conceito torna-se irreversível, pois sabe-se que a inovação está fortemente presente na difusão de todos os conteúdos informativo-comunicacionais, sejam estes profissionais ou de uso individual. Indo da prensa móvel, aos satélites, aos aparelhos de fax, às câmeras fotográficas e de cinema, aos inúmeros modelos de telefone, à internet, a computação em nuvem, às redes sociais, entre outros. Objetivamente falando, a comunicação moderna se concretiza nas tecnologias e nos recursos inovativos que cria e disponibiliza a todos.

Renato Cruz é repórter de tecnologia do jornal Estado e se formou em jornalismo na ECA/USP, onde obteve seu mestrado e doutorado (em TV Digital, 2006) e autor de outros dois livros. $\mathrm{Na}$ presente obra o autor aborda a história de algumas empresas brasileiras de porte (Embrapa, Petrobrás e Embraer, por exemplo), detendo-se nos perfis de multinacionais importantes e com inserção na comunicação, como é ocaso da Cisco, Ericsson e da Google. Para tanto, Cruz segmenta sua abordagem destacando a importância da inovação para as economias dos países, expondo os dados que revelam que o Brasil vem investindo menos de $1 \%$ do seu PIB (enquanto outros países dedicam 2,2\% para tal finalidade), lembrando que o Brasil ficou em 43ํ. em inovação. Apesar de ser a 7ํ. economia mundial (recentemente alcançou a 6ํㅡ. posição), Cruz lembra que o país está em 13‥ lugar na produção científica e 
$24^{\circ}$. no registro de patentes. Os dados expostos na obra são fruto de garimpagem cuidadosa que o autor fez com cientistas e núcleos de pesquisa nas mais importantes universidades brasileiras e em obras relevantes, tanto nacionais quanto estrangeiras.

Fruto ainda de 128 entrevistas pessoais (lista os cientistas destacados e líderes empresariais da criação mundial de tecnologias e procedimentos empresariais) e com linguagem clara e objetiva, o autor aborda a questão da inovação através dos passos da investigação e da ciência iterativa, mas relata também os questionáveis processos da inovação oriunda da imitação deslavada (de parte da indústria coreana, japonesa etc.); enfocando a alta tecnologia dos centros avançados de pesquisa, a energia renovável; o Vale do Silício norte-americano (onde surgiram o Google, a HP, a Apple, o YouTube, o Second Life, o Orkut, o Yahoo, o Facebook etc.).

O autor descreve a história da implantação da TV Digital no país, trazendo à tona as dificuldades (só recentemente superadas) na sua adoção concluindo que isto foi provocado pela ineficiência da interação entre universidade e empresas no Brasil. Ao falar das tecnologias rompedoras, demonstra como os múltiplos e dinâmicos sistemas de trocas de arquivos (que permitem baixar toda sorte de programas de música, de imagens, de vídeos etc.) libertarão os seres dos processos analógicos, cativando contingentes cada vez mais amplos nos sistemas digitais de toda ordem. Nas considerações finais, após lembrar palavras do cientista e inovador Nicholas Negroponte (do MIT) que disse "ser inovador também é ser do contra”, Cruz apresenta os 10 pontos que considera importantes no processo da inovação: 1 . busque a verdade lá fora; 2 . valorize os novos mercados; 3 . desenvolva em rede; 4 . torne as commodities high tech; 5 . compre conhecimento; 6 . persista e mude; 7. gerencie a criatividade; 8 . relativize a voz do cliente; 9. dê espaço para a criatividade e 10. siga o dinheiro.

A obra incorpora bibliografia atualíssima e de alta pertinência ao recorte abordado, incluindo glossário que esclarece os termos e índice remissivo que muito auxilia na localização dos temas e personagens. Assim, e pelas evidências que afloram na obra, é 
possível perceber a urgência na adoção de políticas ainda mais robustas e perenes de investimento em Ciência e Tecnologia, que trarão os caminhos mais consistentes para que o país se insira nos padrões de inovação tão desejados por todos. Por isto tudo, além da obra ser paradigmática para outros setores da ciência, é fundamental para os comunicadores e pesquisadores das Ciências Sociais Aplicadas. 